\title{
Tephrochronology and the extended intimate (integration of ice-core, marine and terrestrial records) event stratigraphy $8-128 \mathrm{ka}$ b2k
}

\author{
Simon P.E. Blockley ${ }^{\mathrm{a}}$ * , Anna J. Bourne ${ }^{\mathrm{b}}$, Achim Brauer ${ }^{\mathrm{c}}$, Siwan M. Davies ${ }^{\mathrm{b}}$, \\ Mark Hardiman ${ }^{\mathrm{d}}$, Poppy R. Harding a , Christine S. Lane e, Alison MacLeod a, \\ Ian P. Matthews ${ }^{\text {a }}$, Sean D.F. Pyne-O'Donnell ${ }^{\mathrm{f}}$, Sune O. Rasmussen ${ }^{\mathrm{g}}$, Sabine Wulf ${ }^{\mathrm{b}}$, \\ Giovanni Zanchetta ${ }^{\mathrm{h}}$
}

a Centre for Quaternary Research, Royal Holloway, University of London, Egham Hill, Surrey, TW20 OEX, UK

${ }^{\mathrm{b}}$ Department of Geography, College of Science, Swansea University, Singleton Park, Swansea, SA2 8PP, Wales, UK

c GFZ German Research Centre for Geosciences, Telegrafenberg, Building C, 14473, Potsdam, Germany

d Department of Geography, University of Portsmouth, Buckingham Building, Lion Terrace, Portsmouth, PO1 3HE, UK

e Geography, University of Manchester, Arthur Lewis Building, Oxford Road, Manchester, M13 9PL, UK

${ }^{f}$ School of Geography, Archaeology and Palaeoecology, Queen's University, Belfast, BT7 1 NN, Northern Ireland, UK

g Centre for Ice and Climate, Niels Bohr Institute, University of Copenhagen, Juliane Maries Vej 30, 2100, Copenhagen, Denmark

${ }^{\mathrm{h}}$ Dipartimento di Scienze della Terra, University of Pisa, Pisa, Italy

\section{A R T I C L E I N F O}

\section{Article history:}

Received 15 February 2014

Received in revised form

30 October 2014

Accepted 4 November 2014

Available online 20 November 2014

\section{Keywords:}

Event-stratigraphy

Tephrochronology

INTIMATE

Greenland ice cores

Palaeoenvironment

Palaeoclimate

\begin{abstract}
A B S T R A C T
The comparison of palaeoclimate records on their own independent timescales is central to the work of the INTIMATE (INTegrating Ice core, MArine and TErrestrial records) network. For the North Atlantic region, an event stratigraphy has been established from the high-precision Greenland ice-core records and the integrated GICCO5 chronology. This stratotype provides a palaeoclimate signal to which the timing and nature of palaeoenvironmental change recorded in marine and terrestrial archives can be compared. To facilitate this wider comparison, without assuming synchroneity of climatic change/proxy response, INTIMATE has also focussed on the development of tools to achieve this. In particular the use of time-parallel marker horizons e.g. tephra layers (volcanic ash). Coupled with the recent temporal extension of the Greenland stratotype, as part of this special issue, we present an updated INTIMATE event stratigraphy highlighting key tephra horizons used for correlation across Europe and the North Atlantic. We discuss the advantages of such an approach, and the key challenges for the further integration of terrestrial palaeoenvironmental records with those from ice cores and the marine realm.
\end{abstract}

(C) 2014 Elsevier Ltd. All rights reserved.

\section{Introduction}

Central to the work of the INTIMATE network has been the comparison of palaeoclimate records based on independent timescales, in order to test for leads and lags in response to climate forcing (Björck et al., 1998; Alloway et al., 2007). In the Northern Hemisphere, this work has focussed on attempts to independently compare palaeoenvironmental proxy-data from the North Atlantic and continental Europe with the high-resolution palaeoclimate archives sampled from within the Greenland Ice Sheet. Due to the

\footnotetext{
* Corresponding author. Tel.: +441784 443405.

E-mail address: simon.blockley@rhul.ac.uk (S.P.E. Blockley).
}

abrupt nature of these climate changes, a long-term challenge has been to robustly resolve the chronologies of different regions with sufficient temporal resolution to assess the phasing and timing of climatic transitions (e.g. Blaauw et al., 2009). One specific aspect of this is to resolve the nature, timing and regional expression of Dansgaard-Oeschger cycles, recorded in Greenland (Dansgaard et al., 1982; Alley et al., 1993), and Heinrich events, recorded in North Atlantic marine records (Heinrich, 1988). These events represent large-scale reorganisations of the ocean-atmosphere system over centennial to millennial timescales, however, the transitions between each climate state can take place in a few decades or less (Steffensen et al., 2008). To fully understand the regional expression of these rapid transitions, high-precision comparisons are required between ice-core, marine and 
terrestrial archives. Comparing regional variation in response to such past changes in all parts of the climate system is critical to resolving the mechanism and pace of climate forcing.

In response to this problem, the INTIMATE community proposed the building of regional event stratigraphies that utilise the highest-resolution and continuous records of climate change within a region, alongside the development of protocols for the independent comparison of other archives. For Europe and the North Atlantic, the Greenland ice core records form the regional stratotype (Björck et al., 1998; Lowe et al., 2008) to which independently dated marine and terrestrial palaeoclimate records may be compared. Comparisons between archives are frequently underpinned by the use of co-located volcanic ash (tephra) isochrons (Lowe et al., 2001, 2008) that provide precise stratigraphic links. A wealth of cryptotephra (volcanic ash layer not visible to the naked eye) studies has greatly added to the number of tephra isochrons described from sites across the North Atlantic and European regions (e.g. Turney et al., 1997, 2004; Wastegård et al., 2000, 2005; Davies et al., 2012). This has resulted in: (1) a significant increase in the potential for inter-site correlations; (2) the identification of key tephra layers that are widespread and that occur within distinct climatic intervals or boundaries (Blockley et al., 2012; Davies et al., 2012); and (3) the development and testing of site age models via direct correlation of widespread archives. The collaborative efforts of researchers from within the INTIMATE community have begun to reveal the importance of tephra correlations in building an understanding of climate system dynamics that would otherwise remain hidden, due to either to the inherent dating uncertainties in individual sites, or the masking of leads and lags through matching of 'wiggles' between climate sequences (Sulpizio et al., 2010; Lane et al., 2013; Rach et al., 2014).

The temporal coverage of the INTIMATE event stratigraphy has now been extended from 8 to $60 \mathrm{ka}$ b2k for the layer counted section of GICC05, and back to $128 \mathrm{ka} \mathrm{b2k}$ for the whole of GICC05modeltext (Rasmussen et al., 2014). This has presented both significant opportunities and new challenges for the independent assessment of the timing of climatic shifts in marine and terrestrial settings. The temporal extension moves the event stratigraphy beyond the range of radiocarbon dating ( $50 \mathrm{ka} \mathrm{b} 2 \mathrm{k})$, where other dating techniques frequently return chronological uncertainties in the order of thousands of years (Austin and Hibbert, 2012). These levels of chronological precision are not sufficient to address questions regarding abrupt climate change, which may take place on sub-decadal to centennial timescales. Tephra studies are therefore likely to play a crucial role in constructing and testing chronologies older than $50 \mathrm{ka} \mathrm{b2k}$, by providing stratigraphic tie-lines and independently derived ageestimates.

Recent research in Southern and Eastern Europe has demonstrated the need for the extension of the INTIMATE event stratigraphic approach across a wider geographical region (Bourne et al., 2010; Blockley et al., 2012; Albert et al., 2013; Feurdean et al., 2014; Cullen et al., 2014), where the effects of the climate changes documented in the North Atlantic realm may be modulated by competing climatic factors. Successful spatial extension entails the identification, chemical analysis and dating of widely distributed ash layers from eruptive centres not previously given full attention within INTIMATE.

Considering the need for both temporal and spatial extension of the INTIMATE tephra framework, two key challenges need to be addressed. The first is the relative paucity of chemically characterised tephra layers that have that have yet been detected in Northern Europe prior to the last termination (c. >15 ka) (Fig. 1a and b). While a detailed record of Icelandic tephra layers is emerging from Greenland (Abbott and Davies, 2012; Bourne et al.,
2013; Rasmussen et al., 2013; Seierstad et al. 2014; Davies et al., 2014; Bourne et al., in press), the pre 15 ka Northern European terrestrial record is currently limited. The limited examples of wellstudied pre-LGM tephra in terrestrial sites include the Stage 5e Klaksvík Tephra found in the Faroe Islands (Wastegård et al., 2005), which is the terrestrial equivalent of 5e-MIDT-RHY from the Nordic sea, and the Stage 3 tephra layer found in the Les Echets sediment sequence, from Eastern France (Veres et al., 2008). This is in contrast to the Southern European tephra record, which is favoured by the presence of a higher number of long and continuous terrestrial sequences (e.g. Wulf et al., 2004; Margari et al., 2007; Vogel et al., 2010). The second challenge is to build a tephra correlation framework that allows for a comparison of archives across the whole of Europe and the North Atlantic region (Blockley et al., 2012; Davies et al., 2012), which would allow comparison of more of the detailed palaeoclimate records generated by the INTIMATE community (e.g. Feurdean et al., 2014; Moreno et al., 2014; Heiri et al., 2014).

Here we will evaluate the tephrostratigraphic resource in Northern Europe between 8 and 128 ka b2k in order to assess how useful this technique may be across this entire timeframe.

In this paper we review the progress of this collaborative effort in three parts: (1) an overview of the revised and geographically extended INTIMATE event stratigraphy, highlighting key tephra layers located in marine, ice core and terrestrial archives from 8 to $60 \mathrm{ka} \mathrm{b2k}$; (2) a review of significant achievements and advances in delineating centennial and sub-centennial climatic events due to tephra correlations; (3) a discussion of the further challenges facing the development of a correlation between Europe and the North Atlantic realm in the extended range of the Greenland stratotype (60-128 ka b2k) (Rasmussen et al., 2014). The discussion of the extension of the Greenland tephra record itself from 60 to $128 \mathrm{ka}$ b2k, along with correlations to the North Atlantic marine record in the extended timeframe, is discussed in a companion paper in this issue Davies et al. (2014).

1 Following the convention in Blockley et al. (2012) all discussions of tephra in relation to the INTIMATE event stratigraphy are in $\mathrm{b} 2 \mathrm{k}$. The use of the b2k scheme is to simplify discussions of timing relative to Greenland and follows reviewers' recommendations from the Blockley et al. (2012) special issue.

\section{Tephrochronology and the INTIMATE event stratigraphy 8-60 ka b2k}

\subsection{The development of the INTIMATE event stratigraphy}

Following recent INTIMATE event stratigraphic schemes we present an updated event stratigraphy for the North Atlantic and European region incorporating key tephra for the period 8-60 ka b2k, covering the whole period of directly layer-counted ice in GICC05 (Fig. 1a). This comprises: (1) the new GICC05 Greenland stratotype from Rasmussen et al. (2014); (2) a list of tephra directly located within the ice core records, updated from Blockley et al. (2012) with the addition of data from Bourne et al. (2013); and (3) the chronostratigraphic positions of tephra from European volcanic centres in the INTIMATE time-frame that are either widespread, or offer the potential of cross-correlation between different volcanic centres. The event stratigraphy is reported as b2k, all tephra ages have been calibrated with IntCal13 (Reimer et al., 2013) and all radiocarbon age models or ${ }^{40} \mathrm{Ar} /{ }^{39} \mathrm{Ar}$ ages have been converted to $\mathrm{b} 2 \mathrm{k}$.

The number of tephra layers within the INTIMATE event stratigraphy has now increased from 72 in 2012 to 88, with a further 10 
a.

GICC05

age (ka b2k)

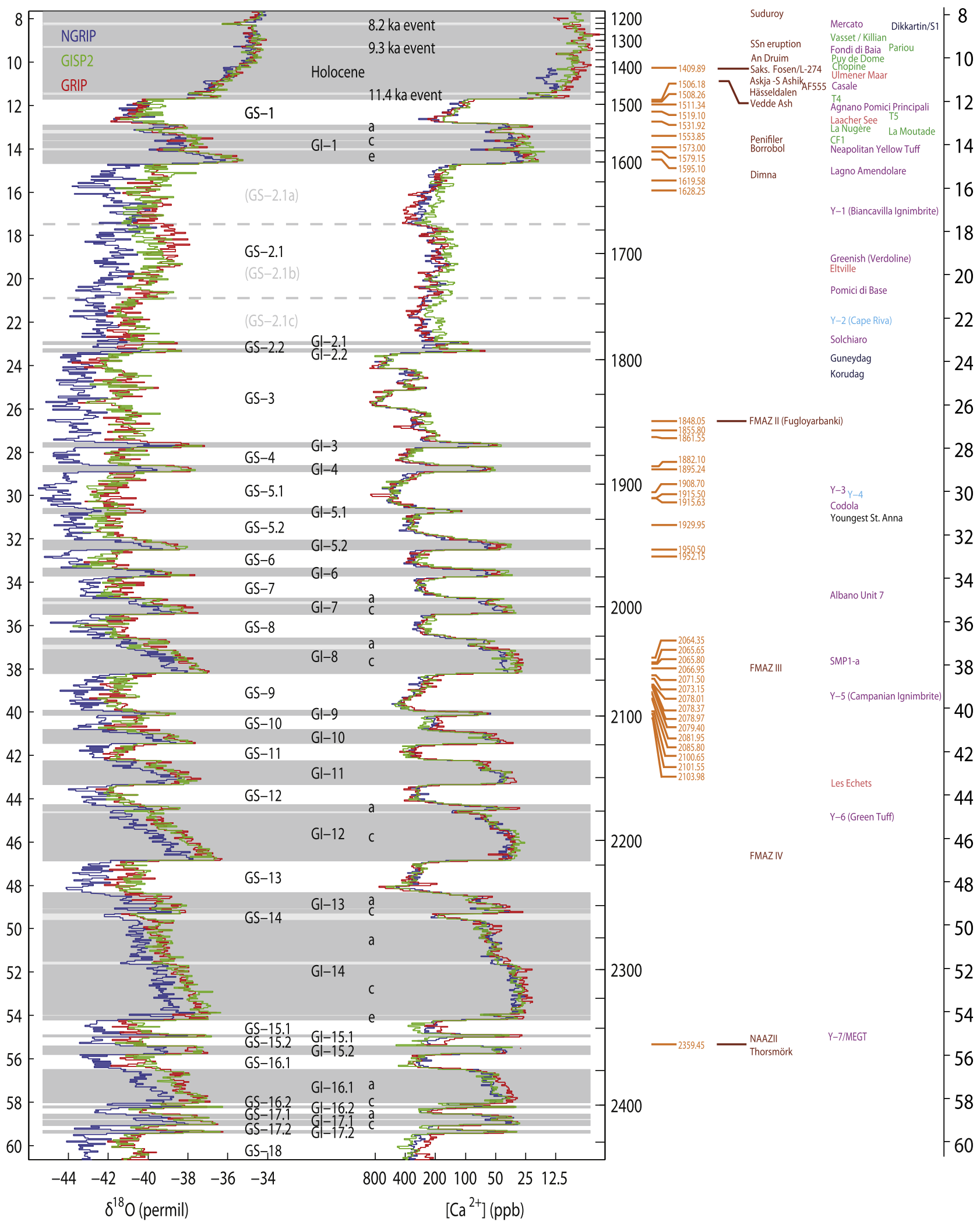

Tephra Event Stratigraphy

NGRIP NGRIP Iceland. J.M./Massif Central depth (m) depth (m) Eifel complex/Italy/Hellenic Arc Anatolian/Carpathian 
tephra discussed in the extended 60-128 ka b2k section (Fig. 1b, Section 3). A significant addition is that of new tephra directly located within the ice core record (Section 2.2) (Bourne et al., 2013) which demonstrates opportunities for future correlations to made between the ice core records and marine and terrestrial archives within and beyond European. Also included are a number of additional tephra from European volcanic centres that, while not at present found within the ice core archive, act as regional stratigraphic markers that can improve cross correlation of other records. This recognises that developing reliable regional chronologies are important for the comparison of centennial scale climate events with the Greenland Stratotype. Where such tephra layers can be well dated they assist in the robust construction of regional chronologies for comparison to the ice cores. The potential of such an approach is exemplified in the work of Matthews et al. (2011) in section 2.2.

The most valuable tephra within the event stratigraphy remain those that are located within the Greenland ice core records as well as terrestrial and marine archives. Exemplified by the $12.2 \mathrm{ka} \mathrm{b} 2 \mathrm{k}$ Vedde Ash (Section 2.2) (Lane et al., 2013), such tephra are key to the construction of a regional tephrostratigraphic framework. Additionally, their precise chronological relationship to other tephra may also be evaluated, with reference to ice core timescales (Lane et al., 2011). The number of directly cross-correlated tephra in the extended event stratigraphy is at present limited, however the development of regional tephrostratigraphic frameworks remains an important goal.

The vast number of volcanic centres (Fig. 2) with the potential to input tephra into palaeoclimate records from the North Atlantic and Europe has both advantages and disadvantages. The main advantage is in the number and distribution of tephra layers potentially available for correlation between archives. However, there are significant challenges in detailing the record of explosive volcanism in terms of, the chronology, dispersal and geochemical variability of tephra from each centre (e.g. Davies et al., 2004; Smith et al., 2011; Tomlinson et al., 2012). Much of this work has been stimulated in Northern European terrestrial and North Atlantic marine contexts by the use of extraction and identification techniques for ash layers not visible to the naked eye (cryptotephra) and these methods are now being applied on a more routine basis (e.g. Lowe et al., 2012). In particular, studies of palaeoenvironmental records in the Mediterranean region have revealed the high-frequency of Italian and Hellenic Arc volcanic eruptions. There are now 19 regionally important tephra layers from the Mediterranean included in the event stratigraphy for the last 8-60 ka b2k (Fig. 1a). Of these, Italian tephra layers are particularly valuable. Besides being detected in many important environmental archives (e.g. Wulf et al., 2004; Bourne et al., 2010; Vogel et al., 2010), many are suitable for dating by a range of techniques, including radiocarbon, ${ }^{40} \mathrm{Ar} /{ }^{39} \mathrm{Ar}$ and varve counting, e.g. the 14 ka b2k Neapolitan Yellow Tuff (Deino et al., 2004; Wulf et al., 2004; Blockley et al., 2008). This allows for a robust comparison of the ages reported for individual tephra layers (Blockley et al., 2008) and the inclusion of valuable absolute age estimates within the age models of our archives. In Section 2.2 we discuss recent examples of how some key Italian tephra layers have helped to constrain abrupt climatic events.

We have increased the number of tephra included in the event stratigraphy from Central European volcanic centres. New additions include the Pariou, Chopine, T4, T5, CF1 and La Moutade tephras from the Massif Central (Juvigne et al., 1996; Vernet et al., 1990; Juvigne and Raynal, 2001; Nowell et al., 2006) and the Eltville Tephra from the Eifel volcanic field (Puclet and Juvigne, 2009). These tephras are limited in number but form part of the long term extension of the INTIMATE framework discussed further in Section 2.4. Further work is clearly required to realise the potential of tephra isochrons from some European volcanic centres. We have also begun to add in eruptions that can potentially act as key markers in the Eastern Mediterranean and the Eastern European regions. Anatolian volcanism has generated numerous locally dispersed tephra layers, but at present few have been widely correlated between sequences. One example, now included within the event stratigraphy is the Dikkartın eruption of Erciyes Dagi (Sarikaya et al., 2006), which correlates to the S1 tephra layer found in a marine core from the Levantine Sea that is dated to 8650-9080 cal b2k (Hamaan et al., 2010). We have also included two eruptions of the Acigöl volcano due to recent dating work on these tephra. These are two closely spaced rhyolitic eruptions, the Guneydag and Korudag, which date to $23,750 \pm 900$ cal years b2k and 24,900 \pm 900 cal years b2k respectively (Schmitt et al., 2011). From the Carpathian arc we were only able to include the youngest eruption of the Ciomadul volcano, which is the last eruption of the St Anna crater. Charcoal from pyroclastic deposits were radiocarbon dated using bulk charcoal and humic acid fractions and a suite of dates that were consistent within errors (AA79952, $27,200 \pm 260 ;$ AA80170, 28,050 \pm 290; AA79951, 27,550 \pm 270 ; AA80169, 27,910 \pm 280$)$. We have combined these dates and recalibrated them using IntCal 13 (Reimer et al., 2013) and this eruption now has an age of 31,090-31,578 cal years b2k. Ongoing work in Eastern European archives (e.g. Cullen et al., 2014) are likely to significantly extend our knowledge of new tephra from these volcanic centres and as some widespread central Mediterranean tephra are also documented in this region there is significant potential to integrate them within the wider Mediterranean tephra framework.

Other volcanic centers, specifically Olot, the Canaries and the Azores (Fig. 2) are reported to have had numerous eruptions during the Late Quaternary, but at present we were unable to identify precisely dated, chemically characterised marker layers that could act as regional isochrons. The scarcity of data on widespread volcanic ash from these regions evidences the need for further studies of the tephra record in sedimentary archives at the western and eastern edges of the current North Atlantic and European INTIMATE study areas.

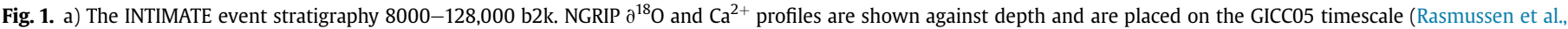

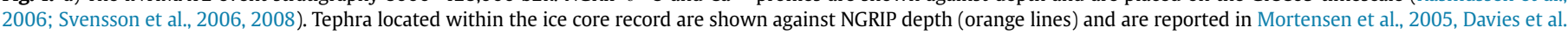

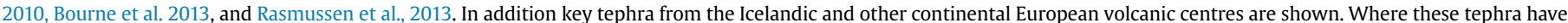

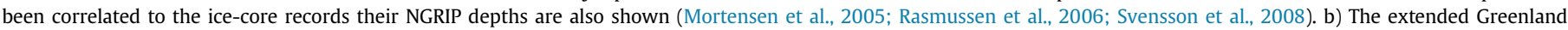

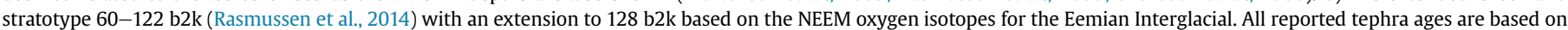

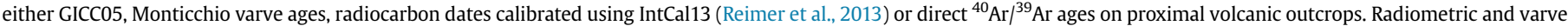

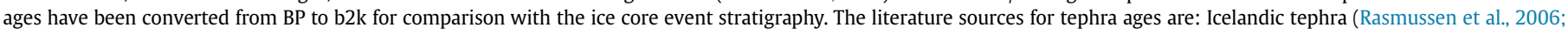

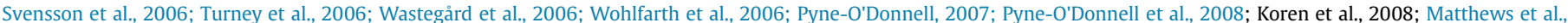

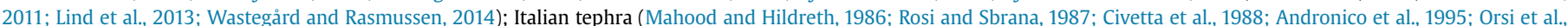

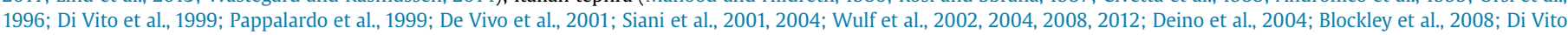

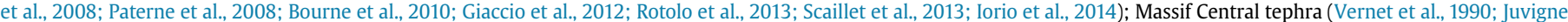

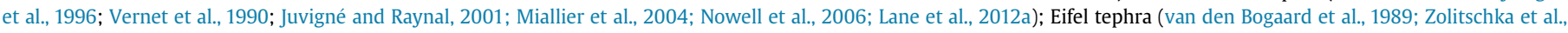
1998; Puclet et al., 2008; Brauer et al., 1999; Puclet and Juvigne, 2009); Hellenic Arc tephra (Federman and Carey, 1980; Margari et al., 2007).
} 


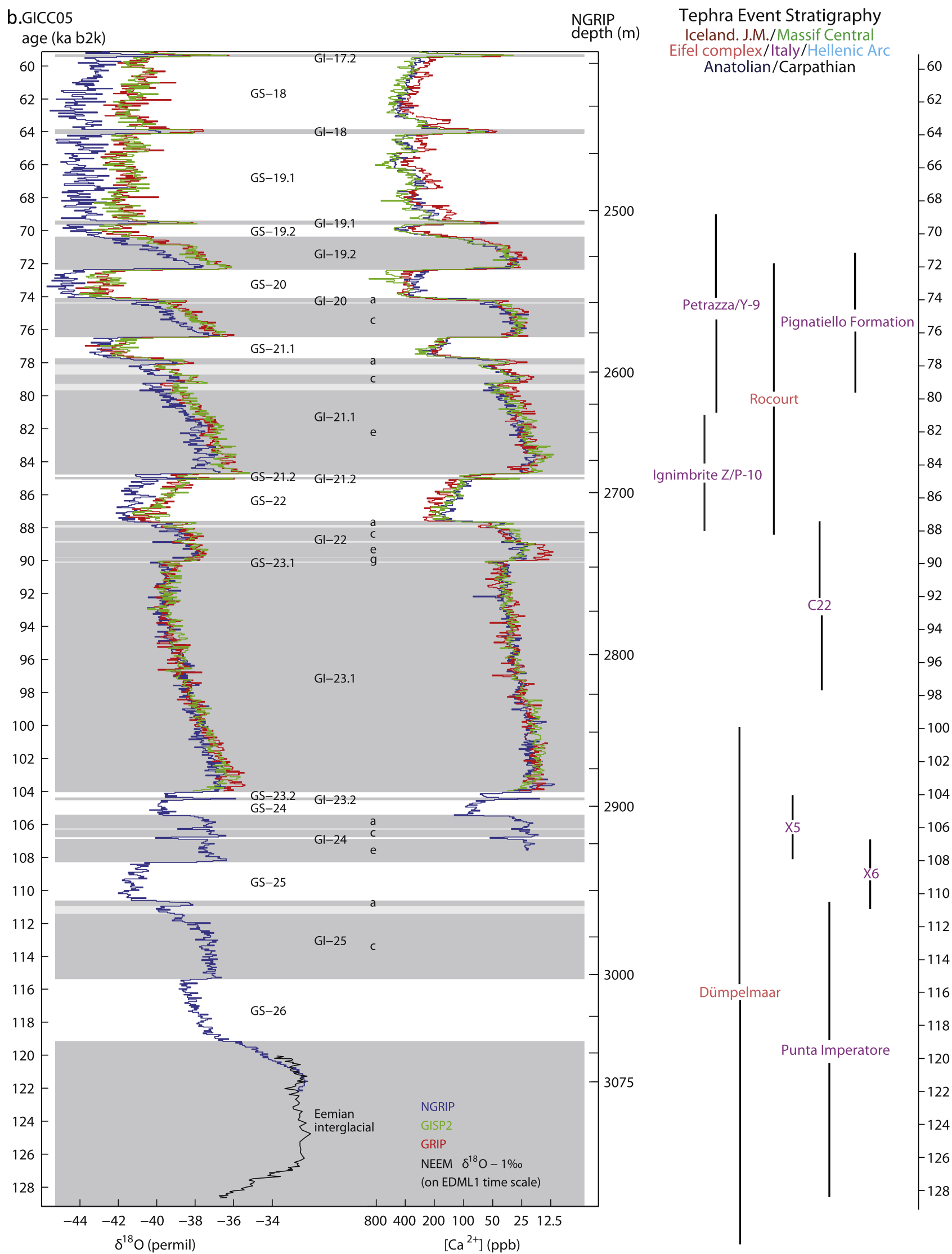

Fig. 1. (continued). 


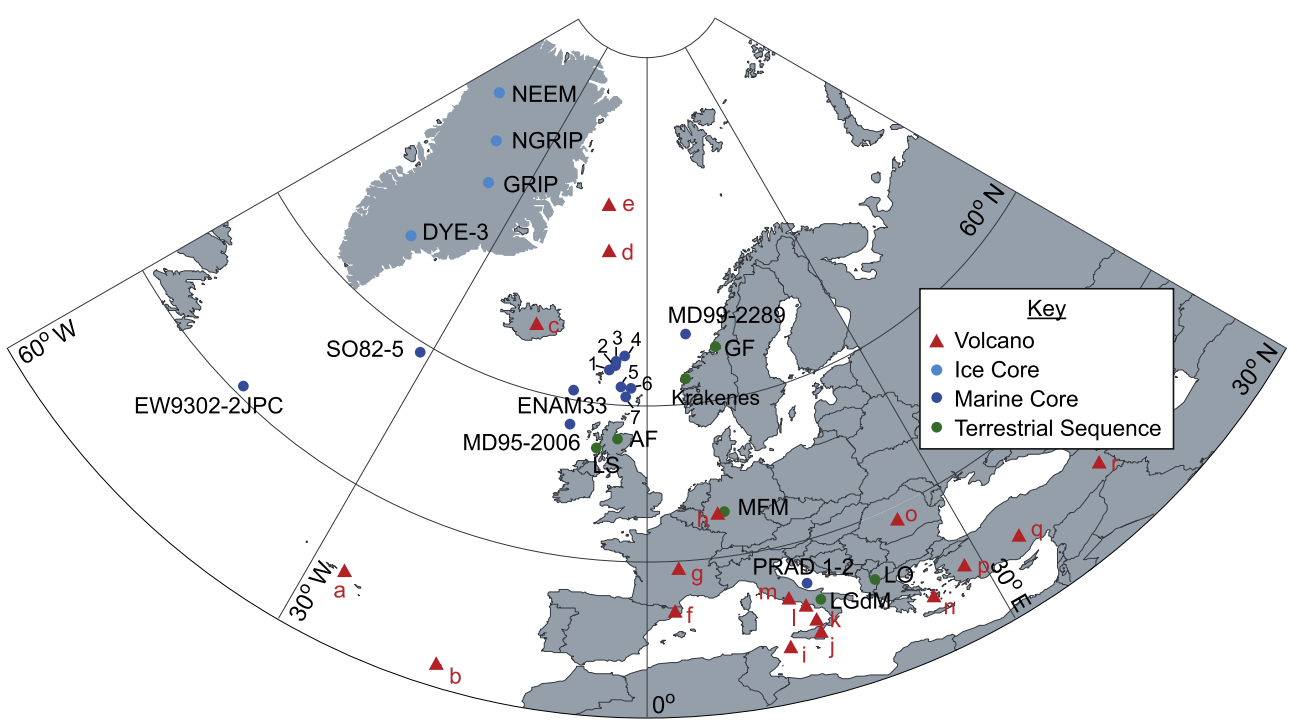

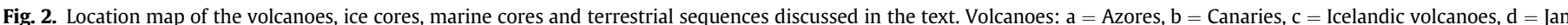

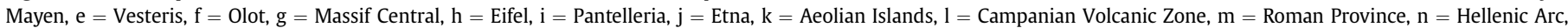

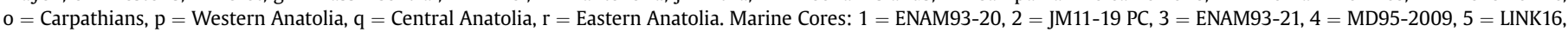

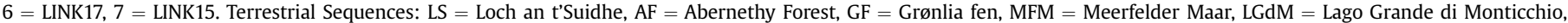
LO $=$ Lake Ohrid

\subsection{The INTIMATE event stratigraphy and constraining centennial- scale climate events}

Tephra correlations have, to date, been widely used as a means of assessing centennial-scale climate variability across Europe; in particular by correlation between terrestrial or marine palaeoenvironmental records, and the Greenland ice-cores. Correlations based upon marine records are particularly challenging when assessing the nature of very abrupt climatic changes, however within the INTIMATE event stratigraphy four tephra layers provide direct tie-lines between the Greenland ice-cores and a number of North Atlantic marine sequences (Davies et al., 2012). These are the North Atlantic Ash Zone (NAAZ) II (55,380 \pm 1184 b2k), Faroe Marine Ash Zone (FMAZ) II (26,740 \pm 390 b2k), Vedde Ash $(12,171 \pm 57 \mathrm{~b} 2 \mathrm{k})$ and the Saksunarvatn Ash $(10,347 \pm 45 \mathrm{~b} 2 \mathrm{k})$ (Fig. 1a). The NAAZ II and FMAZII have been detected in marine cores from across the North Atlantic and are the subject of detailed on-going investigations (cores SO82-05, MD95-2006, MD95-2009 and MD99-2289 for NAAZII (Brendryen et al., 2011); cores EW9302-2JPC, ENAM33, ENAM93-20, ENAM93-21, LINK 15, 16 and 17 (Wastegård et al., 2006) and core JM11-19PC for FMAZII (Griggs et al., 2014); Fig. 2). Of these, the tephra that offers the greatest potential for constraining the rapid climatic events of the Last Glacial period is the NAAZ II. This deposit falls close to a cooling transition at the end of GI-15 and an ice-marine correlation performed by Austin et al., (2004) proposes that this shift was synchronous between the atmosphere and ocean (Abbott and Davies, 2012 - Fig. 8a). Some concerns have been raised, however, that there was a lag in the deposition of this tephra in the marine realm which may affect its use as a time-parallel marker horizon (Brendryen et al., 2011). This emphasises the necessity to assess the integrity of tephra horizons uncovered in the marine realm in order to evaluate the interplay of primary vs secondary depositional processes (e.g. Griggs et al. 2014). As more studies begin to systematically search for the presence of cryptotephra deposits within marine sediment records, it is anticipated that the number of marine-ice tie-points will increase (Bourne et al., 2010; Brendryen et al., 2011; Abbott et al., 2013, 2014).
Interestingly, whilst the four marine-ice tephra horizons mentioned above each have a wide geographical distribution within the North Atlantic region, only the Vedde Ash and Saksunarvatn Ash can be traced within continental sequences as well (Abbott and Davies, 2012; Davies et al., 2012). Until more tephra from the Greenland ice cores are located in continental archives it remains necessary to develop a network of regional tephra isochrons that can assist in the comparison of widespread terrestrial archives with the ice cores, on their own independent timescales (see Brauer et al., 2014). This need for the development of regional tephrostratigraphic frameworks is a significant element of the INTIMATE event stratigraphy.

Within the INTIMATE event stratigraphy we have included a number of tephra that are located across multiple terrestrial sites that have significant potential for enlarging this framework (e.g. Fosen tephra, Vedde Ash, Penifiler tephra, Borrobol tephra; Fig. 1a). The Borrobol and Penifiler tephra layers are key stratigraphic marker layers for the Lateglacial Interstadial and are found in records from Northwest Europe. The two layers are found stratigraphically separate from one another at a number of Scottish sites, including Loch An t'Suidhe, Borrobol (some cores; See Pyne O'Donnell et al., 2007), Abernethy Forest (Matthews et al., 2011) and Loch Ashik (Brooks et al., 2012). When identified in the same sequence and with complementary palaeoclimate data they can be placed clearly within a climatostratigraphic framework (e.g. Brooks et al., 2012). The Borrobol tephra (14,000-14,190 b2k; Matthews et al., 2011) has been used to assess the timing of the onset of organic sedimentation in lakes and consequently has been used to delimit the onset of stable interstadial conditions. The Penifiler tephra (13,700-14,140 b2k) has a more limited distribution and occurs in the middle of the Lateglacial interstadial. In Scotland both layers bracket a distinct cooling event demarked by chironomidinferred mean July temperature reconstructions. The cool event $\left(\sim 4{ }^{\circ} \mathrm{C}\right.$ cooling in mean July temperatures) is replicated across three Scottish sites (Whitrig Bog, Loch Ashik and Abernethy Forest). Whilst these two tephra have not been found within the Greenland ice cores, comparison of the tephra and radiocarbon-based age models for the Scottish sites with GICC05, demonstrates that this 
regionally consistent climatic event occurred contemporaneously with GI-1d cooling in the Greenland stratotype, within the uncertainties of the two records. Greenland counting errors are c. $\pm 160-190$ years in this period whereas Abernethy is c. $\pm 150-170$ years. Therefore, the cooling events may or may not be absolutely contemporaneous but the timing is consistent at the centennial scale (Matthews et al., 2011; Brooks et al., 2012). It is also noticeable that, even in the currently highest resolution chronological study of these two tephra, there is a small overlap in their modelled ages, despite their stratigraphical separation at that site (Matthews et al., 2011). This situation can hopefully be improved in future with additional radiocarbon dating constraints as the density of radiocarbon determinations has a significant impact on the precision of a Bayesian model (see Walker et al., 2012).

We have also included new tephra from the Last Glacial to Interglacial Transition, where a number of tephra isochrons are already known in the North Atlantic region. Some of these are only so far reported from limited sites (e.g. the Dimna ash, AF555) but their location with respect to climate transitions means they could act as important markers if their distribution is better understood in the future. Others in this section are well dated and are found in sites with widespread isochronoes. The Fosen tephra for example is a rhyolitic Icelandic ash that is found in sequences in the Faroe Islands and Norway and sits just above the well-known Saksunarvatn ash (Lind et al., 2013) and has the potential to be a marker for other sites in Europe where a silicic ash has been noted just above the Saksunarvatn.

Away from the Greenland stratotype, centennial scale synchronisation of archives has been provided through the correlation of Italian tephra layers between long lacustrine and marine records in the Mediterranean (e.g. Wulf et al., 2004; Bourne et al., 2010). A number of key Italian tephra are now included within the INTIMATE event stratigraphy, permitting the testing of regional environmental signals across the central Mediterranean region (e.g. Wulf et al., 2004, 2008; Bourne et al., 2010; Vogel et al., 2010). A key feature of this work has been to test the regional synchroneity between climatic oscillations recorded in Mediterranean terrestrial and marine sequences and their relationship with $\mathrm{D}-\mathrm{O}$ cycles recorded in the North Atlantic region.

The second youngest tephra isochron of the INTIMATE timeframe is the Mercato tephra from Somma-Vesuvius, ca $8.4 \mathrm{ka} \mathrm{b2k}$ (Zanchetta et al., 2011). The Mercato tephra, found across sites in the Central Mediterranean and the Balkans, is considered a good marker for correlating terrestrial and marine records during the sapropel S1a interval (Caron et al., 2012) and close to the $8.2 \mathrm{ka} \mathrm{b2k}$ event (Aufgebauer et al., 2012; Damaschke et al., 2013; Caron et al., 2012).

Within the Lateglacial, the Agnano Pomici Principali and the Neapolitan Yellow Tuff tephra layers from Campi Flegrei (southern Italy), have important dispersal axes for correlating the Central Mediterranean, Alpine and Balkan regions. The Agnano Pomici Principali, ca 12.2 ka b2k (Blockley et al., 2008) is a suitable tephra for correlating records spanning the GS-1 time (Sulpizio et al., 2010; Lane et al., 2011). The Neapolitan Yellow Tuff at $14.1 \mathrm{ka} b 2 \mathrm{k}$ is an important marker, positioned shortly after the start of local interstadial warming, contemporary with the Bølling-Allerød and GI-1 (Wulf et al., 2004).

In the Mediterranean there are also a number of well-studied tephra isochrons which allow us to correlate glacial age records. These include: the Y-2/Cape Riva tephra (Santorini) recently dated to ca $21.1 \mathrm{ka}$ b2k (Lee et al., 2013), the Y-3 (Campi Flegrei), recently dated to 29,300-30,110 yrs b2k (Albert et al., in press), the Y-5/ Campanian Ignimbrite ca 39.3 ka b2k (De Vivo et al., 2001) and the Y6 (Pantelleria) dated to $45.7 \pm 1 \mathrm{ka}$ (Scaillet et al., 2013). Of these, the Y3 and Y5 tephra layers are particularly valuable as regional marker horizons as they often occur within notable climatic and palaeoenvironmental excursions: the Y3 tephra is found close to the Heinrich Stadial 3 stadial (Zanchetta et al., 2008), whereas Y5 is considered a marker for Heinrich Stadial 4 (Giaccio et al., 2008). High resolution paleoclimatic records from Sicily channel (Sprovieri et al., 2013) suggest that Y6 is recorded between events in the Mediterranean that are proposed as the equivalents of GS-11 and GI-12. This proposed correlation is in broad agreement with the ${ }^{40} \mathrm{Ar} /{ }^{39} \mathrm{Ar}$ ages reported for this ash when the errors on both ${ }^{40} \mathrm{Ar} /{ }^{39} \mathrm{Ar}$ dates and ice core counting uncertainties are taken into account (Fig. 1a).

These three important tephra horizons of these tephra layers have been found within one notable site from Southern Europe, which is Lake Ohrid, on the border of Macedonia and Albania (Fig. 2) (Keller et al., 1978; Sulpizio et al., 2010; Vogel et al., 2010). This archive provides a stratigraphic archive of Italian volcanism currently spanning back into the last glaciation and future coring endeavours (Wagner et al., 2014) will undoubtedly reveal an even longer record that will be of increasing importance as we think about the construction of a longer INTIMATE event stratigraphy (Section 3).

\subsection{The INTIMATE event stratigraphy and delimiting sub- centennial events}

Within the INTIMATE time-frame there is significant potential for tephra to act as a correlation tool, providing precise chronological constraint for comparison of records at sub-centennial resolution. In rare but important cases annually-resolved records or very high-resolution sediment sequences can be directly linked through common tephra layers. This allows for differential dating between eruptions and/or climate events, providing increased precision in measuring the timing of change between records. In this way, relative uncertainties may be reduced to as little as a decade and it is possible to demonstrate that leads and lags in responses to climate forcing exist, even within local regions (Lane et al., 2013). The coupling, via the identification of the Vedde Ash, between the Greenland stratotype, the German Meerfelder Maar varve record (Brauer et al., 2008) and the high-resolution archive from Kråkenes in Norway, has revealed that the climatic transition in the terrestrial records that marks the separation between the early and late Younger Dryas is asynchronous by up to 120 years (Lane et al., 2013). This has been suggested to indicate a timetransgressive northward shift in the average position of the polar front during the Younger Dryas, marking an atmospheric response to the reactivation of meridional overturning in the North Atlantic. This is an important initial study that sets out a hypothesis that is directly testable by the examination of other high-resolution archives within this region, which contain the Vedde Ash. Additionally, using this tephrostratigraphic linkage the nature of the synchronous onset of Younger Dryas cooling between Greenland and Europe has been elucidated via new biomarker isotopic analyses of the laminated Meerfelder Maar sediments (Rach et al., 2014). It is now confirmed that there is a synchronous drop in temperature in Europe and Greenland, but a lagged change in major environmental and hydrological conditions in Europe, potentially linked to expansion of North Atlantic sea ice and the southerly migration of Westerly winds. These two Meerfelder Maar studies suggest that within the North Atlantic region temperature variability may have been broadly synchronous; however, significant atmospheric and hydrological changes were much more complex. While only representing a component of these two studies, the synchronisation of high-resolution records using tephra was a critical element that allowed the chronological complexity to be elucidated. 
While the presence of one or more tephra layers located in different annually-resolved archives is not common, other occurrences are reported. For example, the Laacher See tephra has been utilised in multiple European archives to determine the precise timing and effective synchroneity of environmental responses to Younger Dryas cooling (Lane et al., 2012a; Wulf et al., 2013). Hence, future studies, within and beyond the INTIMATE initiative, which focus on identifying tephra layers within annually-resolved records are likely to provide a robust means to assess the dynamics of the climate and environmental system during periods of abrupt climatic transition.

\subsection{Challenges in developing the INTIMATE event stratigraphy}

What is clear from Fig. 1a is that there is significant potential for cross-correlation of many widespread archives using tephra layers. However, as yet, only a small number of tephra layers are located in both the North Atlantic ice and marine records and are also widespread across Europe. The challenge for the tephrochronological community therefore, is to generate more cross-correlations between archives.

A clear starting point is the cryptotephra record preserved within the Greenland ice-cores, which to date has been constructed from investigations largely focused on limited sampling windows (Davies et al., 2010; Abbott and Davies, 2012). However, an intense investigation of more than a kilometre of ice spanning the INTIMATE time-period $8-60 \mathrm{ka} \mathrm{b} 2 \mathrm{k}$ is ongoing as part of the TRACE project (Tephra constraints on Rapid Climate Events). Initial results outlined in Bourne et al. (2013) have highlighted the considerable value of adopting a continuous sampling approach for the ice, revealing a far more detailed record of eruptive events than previously realised. This, together with the results of Bourne et al. (in press) identifies 99 tephra layers across 4 Greenland ice-cores between 25 and $45 \mathrm{ka} \mathrm{b2k}$. This includes 19 tephra deposits that lie on the rapid climatic transitions that punctuate the Last Glacial period. The majority of the tephra layers that comprise the Greenland tephra lattice are basaltic in composition (Bourne et al., in press). This presents a further challenge for linking to the Greenland stratotype as basaltic material is not routinely searched for in terrestrial European records.

In addition to continuing work on tephra located within the ice cores and North Atlantic marine records, it is essential to develop our understanding of the distal ash dispersal into terrestrial archives. The majority of the tephra layers located within the North Atlantic region emanate from Icelandic sources and the majority of these are only found in terrestrial sites as in Northern Europe (British Isles, Scandinavia, Germany). Presently, only the Vedde Ash and Askja-S tephra have been reported in Southern Europe, and only the Vedde is known south of the Alps (Lane et al., 2011, 2012b). In part, this relates to the prevailing dispersal axes of Icelandic ash but also reflects the predominance of studies for cryptotephra in northerly regions. Future research on long lake records in Central and Southern Europe may extend the dispersal range of some Icelandic ashes and allow direct correlation of more European records directly with Greenland and the North Atlantic. However, there are still likely to have been only a small number of eruptions that generated ash that travelled both NW to Greenland and SE to the European continent. Thus, a strategy needs to be developed for direct tephra correlation across the whole region. The term for this that has recently come into use is the development of a 'tephra lattice' (Lowe et al., 2012). This involves generating a detailed stratigraphic framework for the correlation of tephra from different volcanic sources, using a widespread network of sedimentary archives. This requires a detailed understanding of the eruptive history of the key volcanic centres and the dispersal pathways of far travelled eruptions. The construction of part of this lattice for Europe is due to be reported in a special issue publication from the UK NERC-funded RESET consortium (Lowe et al., forthcoming). While a slow and painstaking process we believe the benefits of are evident and that this approach could be a valuable means of advancing palaeoclimate studies in many regions of the globe.

In particular it is essential to gain a much better measure of the relative timing of eruptions from Iceland and the Mediterranean volcanic centres in Italy and the Aegean. The former, as mentioned, provide the main tephra input to the Greenland stratotype and will remain the tephra correlation tool for the North Atlantic region, while the latter provide the main tephrostratigraphic framework for correlation in the Mediterranean. A key aim for the future is to be able to develop detailed links across Europe by co-locating Icelandic and European tephra (cf Lane et al., 2011) in annuallyresolved records (e.g. Lago Grande de Monticchio; Allen et al., 1999 ) in Southern Europe, in order to assess longitudinal and latitudinal environmental gradients. However it is still unlikely that many such co-located tephra will be found and thus it is important to also consider tephra from other centres that can bridge the gap. We have, thus, expanded the number of mainland European tephra from north of the Alps in the INTIMATE scheme. This is because they can act as stratigraphic markers within their region and also have the potential to be found in sites that also contain Icelandic and Mediterranean tephra. These include the tephra from the Massif Central and the Eiffel listed in Section 2.1. While these tephra are reported as widespread within these regions and they have the potential in future studies to be found within archives containing more widespread tephra. We also examined the potential for tephra from other volcanic centres to be included within the INTIMATE scheme, specifically Olot and the Azores but at present we were unable to identify specific marker layers that could act as regional isochrons.

\section{Extending the European terrestrial and Mediterranean record of volcanism $60-128 \mathrm{ka}$ b2k}

As outlined in Rasmussen et al., (2014) the Greenland stratotype has been extended from 60 to $128 \mathrm{ka} \mathrm{b} 2 \mathrm{k}$ and a number of new tephra layers have been located within this extended section, increasing the potential for marine and ice-core correlation in the North Atlantic (Davies et al., 2014). This details the current state of knowledge of tephra in the Greenland Ice Cores in this time frame and also the extension of these records into the north Atlantic. A long term goal of members of the INTIMATE tephra community is to provide an extended correlation framework for linking wider archives to this record. Here we briefly focus on the European record away from the North Atlantic that may provide a tephrochronological constraint on European palaeoenvironmental archives. For this purpose there are a number of future possibilities. During the period from 60 to $128 \mathrm{ka} \mathrm{b} 2 \mathrm{k}$ there are several tephra layers that are known to disperse across the Mediterranean (Fig. 1b). These include the Early Glacial X-5 (106.2 $\pm 1.3 \mathrm{ka}$; Giaccio et al., 2012) and X-6 tephras (108.9 $\pm 1.8 \mathrm{ka}$; Iorio et al., 2014), defined initially in marine archives (Keller et al., 1978) as well as a number of eruptions recognized in the long Lago Grande di Monticchio sequence (Wulf et al., 2012), in the Sulmona Basin (Giaccio et al., 2012) and in circum-Central Mediterranean Sea records (e.g., Paterne et al., 2008; Insinga et al., 2014). While it is unlikely these tephra will ever be traced to the North Atlantic, they help to build a robust framework for the chronology of environmental change in this region, which than then be compared independently to the Greenland archive. Bourne et al. (2010), indicated a number of dated eruptions that could be used to link Adriatic marine cores from the Last Glacial with the terrestrial Lago Grande di Monticchio 
archive, and provide absolute ages based on ${ }^{40} \mathrm{Ar} /{ }^{39} \mathrm{Ar}$ dating for comparison with the ice core chronologies. At present, many of these have only low-precision age estimates. However, potassiumrich products of Italian volcanism are suited to high-precision dating by ${ }^{40} \mathrm{Ar} /{ }^{39} \mathrm{Ar}$ and in this timeframe error estimates can be less than a thousand years, if sufficient analyses are undertaken (Mark et al., 2014). Indeed it is possible to achieve error ranges of a few hundred years in ideal settings (De Vivo et al., 2001). While this only allows for millennial-scale correlation between southern Europe and Greenland this would be a significant step forward in the 60-128 ka b2k timeframe.

Along with tephra from the North Atlantic realm (Davies et al., 2014) and the Italian tephra listed above, there is potential for tephra correlation in older sediments in continental Europe. These include older tephra from the Eifel region that have been traced in distal records, such as the Rocourt tephra, a widespread Eifel marker tephra identified in Belgium (Puclet et al., 2008), which at present has a broad age range (90-74 ka b2k). Due to the age and the depositional setting of the Rocourt tephra correlation is at present based on the chemical signature of the mineral suite. An additional Eifel tephra within this time frame that has potential for correlation purposes is the Dümpelmaar tephra. While this tephra is so far not reported beyond the Eifel volcanic fields it has ${ }^{40} \mathrm{Ar} /{ }^{39} \mathrm{Ar}$ radiometric age of $116,000 \pm 16,000$ placing it within MIS 5 and this age is consistent with its stratigraphic position within warm soil forming sediments (van den Bogaard et al., 1989).

Thus while our current knowledge of widespread ash in southern and central European archives is currently limited there are key tephra that do have the potential to underpin a lattice across the Mediterranean (Fig. $1 \mathrm{~b}$ ) but also tephra recorded in long archives closer to the North Atlantic realm. These offer the best possibility for the future to be co-located with either Mediterranean or Icelandic ashes and bridge the gap between these two active volcanic centres, much as has been done in more recent sites within the current 8-60 b2k timeframe (e.g. Lane et al., 2011).

\section{Wider challenges and pitfalls in tephrochronology}

A pressing challenge in tephrochronology highlighted by groups participating in the INTIMATE initiative are the complex decisions that need to be taken when selecting the most reliable techniques to obtain, analyse and present the chemical signatures of individual tephra. The analysis of distal ash requires the precise quantification of major and, in some cases, trace elements of individual glass shards to compare chemical signatures and determine likely correlations. Recent research, including a global intercomparison of EPMA laboratories by (Kuehn et al., 2011) has demonstrated that major-element analyses are viable for glass shards with analytical areas as small as $3 \mu \mathrm{m}$ using refined analytical settings of the latest instruments (Hayward, 2012) while for trace elements analyses are now obtainable on shards with analytical areas $>15 \mu \mathrm{m}$ (Abbott et al., 2012; Lane et al., 2012b), with the potential for further reduction in beam size (Pearce et al., 2011, in press).

In order to fully realise the potential of tephrochronology, and to avoid mis-attribution, we suggest that all tephra correlations require the presentation of precise and accurate compositional datasets. This should include within the publication (or presented on a free access database) the full suite of tephra chemical data, alongside internationally accepted secondary standard data and as suggested by others (e.g. Turney et al., 2004; Newton et al., 2007) full details of instrument operating conditions (for both major and where analysed trace elements). This needs to be coupled with appropriate chronostratigraphic information and a robust assessment of all potential correlatives. It is notable that despite the need for and ability to perform trace elements analysis (Tomlinson et al.,
2010; Pearce et al., 2011) many tephra layers remain characterised by major element compositions alone.

Even with reliable quantification of the geochemical signals many eruptions from the same volcano or volcanic system can have very similar chemistries and care is required for reliable correlation. For example, as Bourne et al. (2013) have shown, the Faroe Marine Ash Zone III (FMAZ III) as preserved in marine records from the North Atlantic is not a single eruption but is likely to be an amalgamation of several different eruptions, which as yet can only be stratigraphically separated in the ice-core records. Chemically these tephras are very similar in the ice-core record, but do exhibit some subtle differences (e.g. $<0.5 \mathrm{wt} \%$ differences in elements such as $\mathrm{TiO}_{2}$ ). As a result those subtle differences mean that robust analyses and reporting of tephra is vital. So the suite of tephras in the ice and the ash zone in the marine cores are probably the same, but the reduced resolution of the marine cores usually prevents us from separating the individual eruptions, although NAAZII can be separated in marine cores in some cases (Haflidason et al., 2000; Wastegård et al., 2006). In this instance correlation is not possible unless you have a stratigraphically and chemically distinct population that corresponds to one of the tephras recorded in the ice (see Fig. 1a).

In terrestrial records Lane et al. (2012b) demonstrate that even deposits from widespread eruptions like the Vedde Ash are not chemically unique. The Vedde Ash is a widespread tephra derived from the Katla volcano in Iceland that is found in mid-Younger Dryas sediments (e.g. Wastegård et al., 2000; Blockley et al., 2007; MacLeod et al., 2014). The Vedde Ash has a wide compositional range, including a geographically limited basalt to basalticandesite component and a far-travelled rhyolitic component. Multiple tephra layers with similar major-element chemistry to the rhyolitic component have been reported within the Last Glacial to Interglacial Transition (e.g. the Suðuroy, AF555 and Dimna ash layers; Wastegård, 2002; Matthews et al., 2011; Koren et al., 2007). Of these eruptions, trace element data are only available for the Vedde Ash and the Dimna Ash, however, it is clear that these two eruptions are compositionally identical. The only means by which to distinguish the two tephra are by their relative stratigraphic positioning and associated chronostratigraphic data (see Fig. 1a for the relative temporal position of these ashes).

Similar problems have recently been revealed from Italian tephras. The Lateglacial Y-1/Biancavilla stratigraphic marker from Mt. Etna has been identified as two eruptive events with very similar chemical signatures across several archives in the Central Mediterranean. These are thought to occur within a 1540 year time interval (Albert et al., 2013) and the potential exists for confusion where either only one layer is detected or insufficient chemical data is available to make a robust comparison. New data on widespread tephras during the Last Glacial, e.g. the Y-5/Campanian Ignimbrite also suggest several eruptions that produced almost identical chemistries within a narrow temporal window (Tomlinson et al., 2012). The spatial and temporal extension of the INTIMATE event stratigraphy will most likely lead to further examples where the robust correlation of ash layers will be limited by extremely similar chemical signatures from closely spaced eruptions further back in time. This will be most problematic in sites where the climatostratigraphic sequence does not respond in the manner of sites in Northern Europe.

These issues are an additional challenge for tephra community and the correlation requirements outlined above, along with other detailed protocols recommended by SCOTAV and INTIMATE (Turney et al., 2004; Davies et al., 2012) are an essential requirement for the ongoing success of the technique.

In order to move beyond millennial-scale comparisons, the challenge is essentially the same as extending tephra-based 
correlation of records to the older parts of the current INTIMATE event stratigraphy. The majority of lake records currently analysed in detail are in the north of the study area and these are on the dispersal axis for most Icelandic tephra detected so far in European records. However, many of the Northern European lakes are formed as postglacial dead ice hollows, following the retreat of ice during the Last Glacial Maximum ( $22 \mathrm{ka} \mathrm{BP})$. Thus, these records are not useful for extending the time frame of tephra-based correlation to the INTIMATE event stratigraphy. At the same time there have been some, limited, cryptotephra studies of long lake records South of the Alps. These have so far not demonstrated the presence of Icelandic ash but they do show that a viable tephra lattice is potentially available for this region, based on tephra from the Mediterranean volcanoes (Sulpizio et al., 2010).

As with the current INTIMATE timeframe the best potential for developing a long term correlation framework between the North Atlantic and southern Europe comes from finding co-located tephra from different volcanic centres. There are a number of long continental lake records south of the limits of LGM ice that have either not yet been studied for cryptotephra, or where only targeted cryptotephra work has been carried out (e.g. Veres et al., 2008). At present little cryptotephra work has been carried out on European lakes outside the Lateglacial and Holocene period and in these cases there are only a few examples containing far-travelled Icelandic tephra reaching Europe south of Northern Germany and the British Isles (e.g. Blockley et al., 2007; Lane et al., 2011). However, the potential for direct correlation of lakes in central Europe certainly exists. The extended range of the Greenland stratotype may also assist in this process. The current period of extensive scrutiny of lake records is the period from $\sim 8$ to $16 \mathrm{ka}$ b2k. It is noteworthy that, within this limited timeframe, two tephra layers of Icelandic origin have been reported from central Europe (Lane et al., 2011, 2012a).

\section{Conclusion}

This paper alongside Davies et al., (2014) updates the tephra contribution to the INTIMATE event stratigraphy, to identify important tephra horizons for the full time range of the existing event stratigraphy. Within this period the most intensively studied section is the deglaciation (8-16 ka b2k) and the potential for tephrochronology to assist in revealing the pattern of climatic and environmental change across the region is now being realised. Moreover, in this period a tephrostratigraphic framework is now being developed that reaches both north and southeast of the European Alps. While there are a number of areas of caution with regards to making reliable correlations, rigorous analytical and stratigraphic protocols are now in place to allow robust correlations to be made and proposed correlations to be tested. These, however, rely on the wider tephra community to publish or make available all chronostratigraphic and chemical data. The challenge now for the INTIMATE group and the wider tephra community is to develop and extend this correlation framework back in time, initially to the limit of the INTIMATE event stratigraphy outlined in Fig. 1a and eventually further back in time across the full range of the Greenland stratotype. We have included this latter extension partly for completeness but it is worth noting that many European lake records extend beyond the current INTIMATE event stratigraphy limits and certainly in the Mediterranean region key widespread tephra markers in the 60-128 ka b2k period are already well known. Thus, there is similar potential for regional cross correlation both within and beyond the current chronological range of INTIMATE

\section{Acknowledgements}

This is a contribution by members of the INTIMATE group (COST Action ES0907 and INQUA IFG CELL-50k) we are also grateful for the contribution by members of the SMART (NE/F020600/1) and RESET projects. This work also contributes toward the aims of the International Focus Group on Tephrochronology (INQUA-INTAV). Bourne and Davies are supported by the European Research Council (TRACE project) under the European Union's Seventh Framework Programme (FP7/2007-2013)/ERC grant agreement no. [259253]. Lane is partly funded by a Leverhulme Trust Early Career Fellowship. We are also grateful to the very useful suggestions and revisions of Stefan Wastegård and an anonymous reviewer.

\section{References}

Abbott, P.M., Davies, S.M., 2012. Volcanism and the Greenland ice-cores: the tephra record. Earth Sci. Rev. 115, 173-191.

Abbott, P.M., Davies, S.M., Steffensen, J.P., Pearce, N.J.G., Bigler, M., Johnsen, S.J., Seierstad, I.K., Svensson, A., Wastegård, S., 2012. A detailed framework of Marine Isotope Stages 4 and 5 volcanic events recorded in two Greenland icecores. Quat. Sci. Rev. 36, 59-77.

Abbott, P.M., Austin, W.E.N., Davies, S.M., Pearce, N.J.G., Hibbert, F.D., 2013. Cryptotephrochronology of the Eemian and the last interglacial-glacial transition in the North East Atlantic. J. Quat. Sci. 28, 501-514.

Abbott, P., Austin, W., Davies, S., Pearce, N., Rasmussen, T., Wastegård, S., Brendryen, J., 2014. Re-evaluation and extension of the Marine Isotope Stage 5 tephrostratigraphy of the Faroe Islands region: the cryptotephra record. Palaeogeogr. Palaeoclimatol. Palaeoecol. 409, 153-168.

Albert, P.G., Tomlinson, E., Lane, C.S., Wulf, S., Smith, V.C., Coltelli, M., Keller, J., Lo Castro, D., Manning, C.J., Müller, W., Menzies, M.A., 2013. Late glacial explosive activity on Mount Etna: implications for proximal-distal tephra correlations and the synchronization of Mediterranean archives. J. Volcanol. Geotherm. Res. 265, $9-26$.

Albert, P.G., Hardiman, M., Keller, J., Tomlinson, E.L., Smith, V.C., Bourne, A.J., Wulf, S., Zanchetta, G., Sulpizio, R., Müller, U.C., Pross, J., Ottolini, L., Matthews, I.P., Blockley, S.P., Menzies, M.A., 2014. Revisiting the Y-3 tephrostratigraphic marker: a new diagnostic glass geochemistry, age estimate, and details on its climatostratigraphical context. Quat. Sci. Rev. http://dx.doi.org/ 10.1016/j.quascirev.2014.04.002 (in press).

Allen, J.R.M., Brandt, U., Brauer, A., Hubberten, H.-W., Huntley, B., Keller, J., Kraml, M., Mackensen, A., Mingram, J., Negendank, J.F.W., Nowaczyk, N.R. Oberhänsli, H., Watts, W.A., Wulf, S., Zolitschka, B., 1999. Rapid environmental changes in southern Europe during the last glacial period. Nature 400, 740-743.

Alley, R.B., Meese, D.A., Shuman, C.A., Gow, A.J., Taylor, K.C., Grootes, P.M. White, J.W.C., Ram, M., Waddington, E.D., Mayewski, P.A., Zielinski, G.A., 1993. Abrupt increase in Greenland snow accumulation at the end of the Younger Dryas event. Nature 362, 527-529.

Alloway, B.V., Lowe, D.J., Barrell, D.J.A., Newnham, R.M., Almond, P.C., Augustinus, P.C., Bertler, N.A.N., Carter, L.C., Litchfield, L.C., McGlone, M.S., Shulmeister, J., Vandergoes, M.J., Williams, P.W., NZ-INTIMATE Members, 2007. Towards a climate event stratigraphy for New Zealand over the past 30,000 years. J. Quat. Sci. 22, 9-35.

Andronico, D., Calderoni, G., Cioni, R., Sbrana, A., Sulpizio, R., Santacroce, R., 1995. Geological map of Somma-Vesuvius volcano. Period. Mineral. 64, 77-78.

Aufgebauer, A., Panagiotopoulos, K., Wagner, B., Schäbitz, F., Viehberg, F.A., Vogel, H., Zanchetta, G., Sulpizio, R., Leng, M.J., Damaschke, M., 2012. Climate and environmental change in the Balkans over the last 17 ka recorded in sediments from Lake Prespa (Albania/F.Y.R. of Macedonia/Greece). Quat. Int. 274, 122-135.

Austin, W.E.N., Hibbert, F.D., 2012. Tracing time in the ocean: a brief review of chronological constraints (60-8 kyr) on North Atlantic marine event-based stratigraphies. Quat. Sci. Rev. 36, 28-37.

Austin, W.E.N., Wilson, L.J., Hunt, J.B., 2004. The age and chronostratigraphical significance of North Atlantic Ash Zone II. Journal of Quaternary Science 19, $137-146$.

Björck, S., Walker, M.J.C., Cwynar, L., Johnsen, S.J., Knudsen, K.L., Lowe, J.J., Wohlfarth, B., INTIMATE Members, 1998. An event stratigraphy for the Last Termination in the North Atlantic region based on the Greenland Ice Core record: a proposal by the INTIMATE group. J. Quat. Sci. 13, 283-292.

Blaauw, M., Wohlfarth, B., Christen, J.A., Ampel, L., Veres, D., Hughen, K.A., Preusser, F., Svensson, A., 2009. Were last glacial climate events simultaneous between Greenland and France? A quantitative comparison using non-tuned chronologies. J. Quat. Sci. 25, 387-394.

Blockley, S.P.E., Lane, C.S., Lotter, A.F., Pollard, A.M., 2007. Evidence for the presence of the Vedde Ash in Central Europe. Quat. Sci. Rev. 26, 3030-3036.

Blockley, S.P.E., Bronk Ramsey, C., Pyle, D.M., 2008. Improved age modelling and high-precision age estimates of late Quaternary tephras, for accurate palaeoclimate reconstruction. J. Volcanol. Geotherm. Res. 177, 251-262.

Blockley, S.P.E., Lane, C.S., Hardiman, M., Rasmussen, S., Seierstad, I., Steffensen, J.P., Svensson, A., Lotter, A.F., Turney, C.S., Ramsey, C.B., INTIMATE members, 2012. 
Synchronisation of palaeoenvironmental records over the last 60,000 years, and an extended INTIMATE event stratigraphy to 48,000 b2k. Quat. Sci. Rev. 36, $2-10$.

Bourne, A.J., Lowe, J.J., Trincardi, F., Asioli, A., Blockley, S.P.E., Wulf, S., Matthews, I.P., Piva, A., Vigliotti, L., 2010. Distal tephra record for the last ca 105,000 years from core PRAD 1-2 in the central Adriatic Sea: implications for marine tephrostratigraphy. Quat. Sci. Rev. 29, 3079-3094.

Bourne, A.J., Davies, S.M., Abbott, P.M., Rasmussen, S.O., Steffensen, J.P., Svensson, A., 2013. Revisiting the Faroe Marine Ash Zone III in two Greenland ice cores: implications for marine-ice correlations. J. Quat. Sci. 28, 641-646.

Bourne, A.J., Cook, E., Abbott, P.M., Seierstad, I.K., Steffensen, J.P., Svensson, A., Schüpbach, S., Fischer, H., Davies, S.M., 2014. A tephra lattice for Greenland and a reconstruction of volcanic events spanning 25-45 ka b2k. Quat. Sci. Rev. (in press).

Brauer, A., Endres, C., Günter, C., Litt, T., Stebich, M., Negendank, J.F.W., 1999. High resolution sediment and vegetation responses to Younger Dryas climate change in varved lake sediments from Meerfelder Maar, Germany. Quat. Sci. Rev. 18, $321-329$.

Brauer, A., Haug, G.H., Dulski, P., Sigman, D.M., Negendank, J.F.W., 2008. An abrupt wind shift in western Europe at the onset of the Younger Dryas cold period. Nat. Geosci. 1, 520-523.

Brauer, A., Hajdas, I., Blockley, S.P.E., Bronk Ramsey, C., Christl, M., Ivy-Ochs, S., Moseley, G., Nowaczyk, N.N., Rasmussen, S.O., Roberts, H., Spötl, C., Staff, R., Svensson, A., 2014. The importance of independent chronology in integrating records of past climate change for the 60-8 ka INTIMATE time interval. Quat. Sci. Rev. 106, 47-66.

Brendryen, J., Haflidason, H., Sejrup, H.P., 2011. Non-synchronous deposition of North Atlantic Ash Zone II in Greenland ice cores, and North Atlantic and Norwegian Sea sediments: an example of complex glacial-stage tephra transport. J. Quat. Sci. 26, 739-745.

Brooks, S.J., Matthews, I.P., Birks, H.H., Birks, H.J.B., 2012. High resolution Lateglacial and early-Holocene summer air temperature records from Scotland inferred from chironomid assemblages. Quat. Sci. Rev. 41, 67-82.

Caron, B., Siani, G., Sulpizio, R., Zanchetta, G., Paterne, M., Santacroce, R., Tema, E., Zanella, E., 2012. Late Pleistocene to Holocene tephrostratigraphic record from the Northern Ionian Sea. Mar. Geol. 311-314, 41-51.

Civetta, L., Cornette, Y., Gillot, P.-Y., Orsi, G., 1988. The eruptive history of Pantelleria (Sicily Channel) in the last 50 ka. Bull. Volcanol. 50, 47-57.

Cullen, V., Smith, V.C., Arz, H.W., 2014. The detailed tephrostratigraphy of a core from the south-east Black Sea spanning the last 60 ka. J. Quat. Sci. 29 (7), $675-690$.

Damaschke, M., Sulpizio, R., Zanchetta, G., Wagner, B., Böhm, A., Nowaczyk, N., Rethemeyer, J., Hilgers, A., 2013. Tephrostratigraphic studies on a sediment core from Lake Prespa in the Balkans. Clim. Past 9, 267-287.

Dansgaard, W., Clausen, H.B., Gundestrup, N., Hammer, C.U., Johnsen, S.F., Kristinsdottir, P.M., Reeh, N., 1982. A new Greenland deep ice core. Science 218, 1273-1277.

Davies, S.M., Wohlfarth, B., Wastegård, S., Blockley, S.P.E., Possnert, G., 2004. Were there two Borrobol Tephras in the early Late-glacial (GI-1): implications for tephrochronology? Quat. Sci. Rev. 23, 581-589.

Davies, S.M., Wastegård, S., Abbott, P.M., Barbante, C., Bigler, M., Johnsen, S.J., Rasmussen, T.L., Steffensen, J.P., Svensson, A., 2010. Tracing volcanic events in the NGRIP ice-core and synchronising North Atlantic marine records during the last glacial period. Earth Planet. Sci. Lett. 294, 69-79. http://dx.doi.org/10.1016/ j.epsl.2010.03.004.

Davies, S., Abbott, P.M., Pearce, N.J., Wastegård, S., Blockley, S.P.E., 2012. Integrating the INTIMATE records using tephrochronology: rising to the challenge. Quat. Sci. Rev. 36, 11-27.

Davies, S.M., Abbott, P.M., Meara, R.H., Pearce, N.J.G., Austin, W.E.N., Chapman, M.R., Svensson, A., Bigler, M., Rasmussen, T.L., 2014. A North Atlantic tephra framework for 130,000-60,000 years b2k: new tephra discoveries, marine basedcorrelations and future challenges. Quat. Sci. Rev. 106, 101-121.

de Vivo, B., Rolandi, G., Gans, P.B., Calvert, A., Bohrson, W.A., Spera, F.J., Belkin, H.E., 2001. New constraints on the pyroclastic eruptive history of the Campanian volcanic Plain (Italy). Mineral. Petrol. 73, 47-65.

Deino, A.L., Orsi, G., de Vita, S., Piochi, M., 2004. The age of the Neapolitan Yellow Tuff caldera-forming eruption (Campi Flegrei caldera d Italy) assed by ${ }^{40} \mathrm{Ar} /{ }^{39} \mathrm{Ar}$ dating method. J. Volcanol. Geotherm. Res. 133, 157-170.

Di Vito, M.A., Isaia, R., Orsi, G., Southon, J., de Vita, S., Antonio, M.D., Pappalardo, L., Piochi, M., 1999. Volcanism and deformation since 12,000 years at the Campi Flegrei caldera (Italy). J. Volcanol. Geotherm. Res. 91, 221-246.

Di Vito, M.A., Sulpizio, R., Zanchetta, G., D'Orazio, M., 2008. The late Pleistocene pyroclastic deposits of the Campanian Plain: new insights into the explosive activity of Neapolitan volcanoes. J. Volcanol. Geotherm. Res. 177, 19-48.

Federman, A.N., Carey, S.N., 1980. Electron microprobe correlation of tephra layers from eastern Mediterranean abyssal sediments and the island of Santorini. Quat. Res. 13, 160-171.

Feurdean, A., Perşoiu, A., Tanţău, I., Stevens, T., Magyari, E., Onac, B., Marković, S., Andrič, M., Connor, S., Fărcaş, S., Gałka, M., Gaudeny, T., Hoek, W., Kolaczek, P., Kuneš, P., Lamentowicz, M., Marinova, E., Michczyńska, D., Perşoiu, I., Płóciennik, M., Slowinski, M., Stancikaite, M., Sumegi, P., Svensson, A., Tămaş, T., Timar, A., Tonkov, S., Toth, M., Veski, S., Willis, K., Zernitskaya, V., 2014. Climate variability and associated vegetation response throughout Central and Eastern Europe (CEE) between 60 and 8 ka. Quat. Sci. Rev. 106, 206-224.
Giaccio, B., Isaia, R., Fedele, F.G., Di Canzio, E., Hoffecker, J., Ronchitelli, A., Sinitsyn, A., Anikovich, M., Lisitsyn, S.N., 2008. The Campanian Ignimbrite and Codola tephra layers: two temporal/stratigraphic markers for the Early Upper Palaeolithic in southern Italy and Eastern Europe. J. Volcanol. Geotherm. Res. $177,208-226$.

Giaccio, B., Nomade, S., Wulf, S., Isaia, R., Sottili, G., Cavuoto, G., Galli, P., Messina, P., Sposato, A., Sulpizio, R., Zanchetta, G., 2012. The late MIS 5 Mediterranean tephra markers: a reappraisal from peninsular Italy terrestrial records. Quat. Sci. Rev. 56, 31-45.

Griggs, A.J., Davies, S.M., Abbott, P.M., Rasmussen, T.L., Palmer, A.P., 2014. Optimising the use of marine tephrochronology in the North Atlantic: a detailed investigation of the Faroe Marine Ash Zones II, III and IV. Quat. Sci. Rev. http:// dx.doi.org/10.1016/j.quascirev.2014.04.031.

Haflidason, H., Eiríksson, J., van Kreveld, S., 2000. The tephrochronology of Iceland and the North Atlantic region during the Middle and Late Quaternary: a review. J. Quat. Sci. 15, 3-22.

Hamann, Y., Wulf, S., Ersoy, O., Ehrmann, W., Aydar, E., Schmiedl, G., 2010. First evidence of a distal early Holocene ash layer in the Eastern Mediterranean deep-sea sediments derived from the Anatolian volcanic province. Quat. Res. 73, 497-506.

Hayward, C., 2012. High spatial resolution electron probe microanalysis of tephras and melt inclusions without beam-induced chemical modification. Holocene 22, 119-125.

Heinrich, H., 1988. Origin and consequences of cyclic ice rafting in the Northeast Atlantic Ocean during the past 130,000 years. Quat. Res. 29, 142-152.

Heiri, O., Koinig, K.A., Spötl, C., Barrett, S., Brauer, A., Drescher-Schneider, R., Gaar, D. Ivy-Ochs, S., Kerschner, H., Luetscher, M., Moran, A., Nicolussi, K., Preusser, F. Schmidt, R., Schoeneich, P., Schwörer, C., Sprafke, T., Terhorst, B., Tinner, W., 2014. Palaeoclimate records 60-8 ka in the Austrian and Swiss Alps and their forelands. Quat. Sci. Rev. 106, 186-205.

Insinga, D.D., Tamburrino, S., Lirer, F., Vezzoli, L., Barra, M., De Lange, G.J., Tiepolo, M., Vallefuoco, M., Mazzola, S., Sprovieri, M., 2014. Tephrochronology of the astronomically-tuned KC01B deep-sea core, Ionian Sea: insights into the explosive activity of the Central Mediterranean area during the last $200 \mathrm{ka}$. Quat. Sci. Rev. 85, 63-84.

Iorio, M., Liddicoat, J., Budillon, F., Incoronato, A., Coe, R.S., Insinga, D.D. Cassata, W.S., Lubritto, C., Angelino, A., Tamburrino, S., 2014. Combined palaeomagnetic secular variation and petrophysical records to time-constrain geological and hazardous events: an example from the eastern Tyrrhenian Sea over the last $120 \mathrm{ka}$. Glob. Planet. Change 113, 91-109.

Juvigné, E.T., Raynal, J.-P. (Eds.), 2001. Tephras-Chronology, Archaeology. Les Dossiers de l'Archaeo-Logis 1, pp. 1-262.

Juvigné, E.T., Bastin, B., Delibrias, G., Evin, J., Gewelt, M., Gilot, E., Streel, M.A., 1996 A comprehensive pollen- and tephra-based chronostratigraphic model for the Late Glacial and Holocene period in the French Massif Central. Quat. Int. 34-36, 113-120.

Keller, J., Ryan, W.B.F., Ninkovich, D., Altherr, R., 1978. Explosive volcanic activity in the Mediterranean over the past 200,000 yr as recorded in deep-sea sediments. Geol. Soc. Am. Bull. 89, 591-604.

Koren, J.H., Svendsen, J.I., Mangerud, J., Furnes, H., 2007. The Dimna ash a $12.814 \mathrm{C}$ Ka-old volcanic ash in Western Norway. Quat. Sci. Rev. 27, 85-94.

Kuehn, S.C., Froese, D.G., Shane, P.A.R., INTAV Intercomparison Participants, 2011. The INTAV intercomparison of electron-beam microanalysis of glass by tephrochronology laboratories: results and recommendations. Quat. Int. 246, 19-47.

Lane, C.S., Andric, M., Cullen, V.L., Blockley, S.P.E., 2011. The occurrence of dista Icelandic and Italian tephra in the Lateglacial of Lake Bled, Slovenia. Quat. Sci. Rev. 30, 1013-1018.

Lane, C.S., Blockley, S.P.E., Lotter, A.F., Finsinger, W., Filippi, M.L., Matthews, I.P. 2012a. A regional tephrostratigraphic framework for central and southern European climate archives during the Last Glacial to Interglacial Transition: comparisons north and south of the Alps. Quat. Sci. Rev. 36, 50-58.

Lane, C.S., Blockley, S.P.E., Smith, V.C., Mangerud, J., Bronk Ramsey, C., Tomlinson, E. Menzies, M., 2012b. Was the 12.1 ka Icelandic Vedde Ash one of a kind? Quat. Sci. Rev. 33, 87-99.

Lane, C.S., Brauer, A., Blockley, S.P.E., Dulski, P., 2013. Volcanic ash reveals timetransgressive abrupt climate change during the Younger Dryas. Geology 41, $1251-1254$.

Lee, S., Ramsey, C., Hardiman, H., 2013. Modeling the age of the Cape Riva (Y-2) tephra. Radiocarbon 55, 741-747.

Lind, E.M., Wastegård, S., Larsen, J.J., 2013. A Late Younger Dryas-Early Holocene tephrostratigraphy for Fosen, Central Norway. J. Quat. Sci. 28, 803-811.

Lowe, J.J., Hoek, W., INTIMATE Group, 2001. Inter-regional correlation of palaeoclimatic records for the Last Glacial-Interglacial Transition: a protocol for improved precision recommended by the INTIMATE project group. Quat. Sci. Rev. 20, 1175-1187.

Lowe, J.J., Rasmussen, S.O., Björck, S., Hoek, W.Z., Steffensen, J.P., Walker, M.J.C., Yu, Z.C., 2008. Synchronisation of palaeoenvironmental events in the North Atlantic region during the Last Termination: a revised protocol recommended by the INTIMATE group. Quat. Sci. Rev. 27, 6-17.

Lowe, J.J., Barton, N., Blockley, S.P.E., Bronk Ramsey, C., Cullen, V., Davies, W., Gamble, C., Grant, K., Hardiman, M., Housley, R., Lane, C.S., Lee, S., Lewis, M., MacLeod, A., Menzies, M., Müller, W., Pollard, M., Price, C., Roberts, A.P., Rohling, E.J., Satow, C., Smith, V.C., Stringer, C.B., Tomlinson, E.L., White, D. Albert, P., Arienzo, I., Barker, G., Boric, D., Carandente, A., Civetta, L., Ferrier, C., Gaudelli, J.-L., Karkanas, P., Koumouzelis, M., Muller, U.C., Orsi, G., Pross, J., 
Rosi, M., Shalamanov-Korobar, L., Sirakov, N., Tzedakis, P.C., 2012. Volcanic ash layers illuminate the resilience of Neanderthals and early Modern Humans to natural hazards. Proc. Natl. Acad. Sci. U. S. A. 109, 13532-13537.

Lowe, J.J., Housley, R.A., Tomlinson, E.L., 2014. The RESET project (RESponse to Abrupt Transitions): synchronising environmental and Archaeological records using volcanic ash Isochrones. Quat. Sci. Rev. (special issue, forthcoming).

MacLeod, A., Brunnberg, L., Wastegård, S., Hang, I.P., Matthews, I.P., 2014. Lateglacial cryptotephra detected within clay varves in Östergötland, south-east Sweden. J. Quat. Sci. 29, 605-609.

Mahood, G.A., Hildreth, W., 1986. Geology of the peralkaline volcano at Pantelleria, Strait of Sicily. Bull. Volcanol. 48, 143-172.

Margari, V., Pyle, D.M., Bryant, C., Gibbard, P., 2007. Mediterranean tephra stratigraphy revisited: results from a long terrestrial sequence from Lesvos Island, Greece. J. Volcanol. Geotherm. Res. 163, 34-54.

Mark, D.F., Petraglia, M., Smith, V.C., Morgan, L.E., Barfod, D.N., Ellis, B.S., Pearce, N.J., Pall, J.N., Korisettar, R., 2014. A high-precision ${ }^{40} \mathrm{Ar} /{ }^{39} \mathrm{Ar}$ age of the Young Toba Tuff and dating of ultra-distal tephra: forcing of Quaternary climate and implications for hominin occupation of India. Quat. Geochronol. 18, 173-175.

Matthews, I.P., Birks, H.H., Bourne, A.J., Brooks, S.J., Lowe, J.J., MacLeod, A., PyneO'Donnell, S.D.F, 2011. New age estimates and climatostratigraphic correlations for the Borrobol and Penifiler Tephras: evidence from Abernethy Forest, Scotland. J. Quat. Sci. 26, 247-252.

Miallier, D., Michon, L., Évin, J., Pilleyre, T., Sanzelle, S., Vernet, G., 2004. Volcans de la chaîne des Puys (Massif Central, France): point sur la chronologie VassetKilian-Pariou-Chopine. C. R. Geosci. 336, 1345-1353.

Moreno, A., Svensson, A., Brooks, S.J., Connor, S., Engels, S., Fletcher, W., Genty, D., Heiri, O., Labuhn, I., Persoiu, A., Peyron, O., Sadori, L., Valero-Garcés, B., Wulf, S. Zanchetta, G., data contributors, 2014. A compilation of Western European terrestrial records 60-8 ka BP: towards an understanding of latitudinal climatic gradients. Quat. Sci. Rev. (in this isue).

Mortensen, A.K., Bigler, M., Grönvold, K., Steffensen, J.P., Johnsen, S.J., 2005. Volcanic ash layers from the Last Glacial Termination in the NGRIP ice core. J. Quat. Sci. 20, 209-219.

Newton, A.J., Dugmore, A.J., Gittings, B.M., 2007. Tephrabase: tephrochronology and the development of a centralised European database. J. Quat. Sci. 22, 737-743.

Nowell, D.A.G., Jones, C.M., Pyle, D.M., 2006. Episodic Quaternary volcanism in France and Germany. J. Quat. Sci. 21, 645-675.

Orsi, G., De Vita, S., Di Vito, M., 1996. The restless, resurgent Campi Flegrei nested caldera (Italy): constraints on its evolution and configuration. J. Volcanol. Geotherm. Res. 74, 179-214.

Pappalardo, L. Civetta, L., D'Antonio, M., Deino, A., Di Vito, M., Orsi, G., Carandente, A., de Vita, S., Isaia, R., Piochi, M., 1999. Chemical and Sr-isotopical evolution of the Phlegrean magmatic system before the Campanian Ignimbrite and the Neapolitan Yellow Tuff eruptions. J. Volcanol. Geotherm. Res. 91, $141-166$.

Paterne, M., Guichard, F., Duplessy, J.C., Siani, G., Sulpizio, R., Labeyrie, J., 2008 A 90,000-200,000 yrs marine tephra record of Italian volcanic activity in the Central Mediterranean Sea. J. Volcanol. Geotherm. Res. 177, 187-196.

Pearce, N.J.G., Perkins, W.T., Westgate, J.A., Wade, S.C., 2011. Trace-element microanalysis by LA-ICP-MS: the quest for comprehensive chemical characterisation of single, sub-10 mu m volcanic glass shards. Quat. Int. 246, 57-81.

Pearce, N.J.G., Abbott, P.M., Martin-Jones, C., 2014. Microbeam methods for the analysis of glass in fine grained tephra deposits: a SMART perspective on current and future trends. In: Austin, W.E.N., Abbott, P.M., Davies, S.M. Pearce, N.J.G., Wastegård, S. (Eds.), Marine Tephrochronology, Geological Society of London Special Publication 398, pp. 29-46.

Puclet, A., Juvigne, E., 2009. The Eltville Tephra, a late Pleistocene widespread tephra layer in Germany, Belgium and the Netherlands; symptomatic compositions of the minerals. Geol. Belg. 12, 93-103.

Puclet, A., Juvigne, E., Pirson, S., 2008. The Rocourt Tephra, a widespread 90-74 ka stratigraphic marker in Belgium. Quat. Res. 70, 105-120.

Pyne-O'Donnell, S.D.F., 2007. Three new distal tephras in sediments spanning the Last Glacial-Interglacial Transition in Scotland. J. Quat. Sci. 22, 559-570.

Pyne-O'Donnell, S.D.F., Blockley, S.P.E., Turney, C.S.M., Lowe, J.J., 2008. Distal volcanic ash layers in the Lateglacial Interstadial (GI-1) problems of stratigraphic discrimination. Quat. Sci. Rev. 27, 72-84.

Rach, O., Brauer, A., Wilkes, H., Sachse, D., 2014. Delayed hydrological response to Greenland cooling at the onset of the Younger Dryas in western Europe. Nat. Geosci. 7, 109-112.

Rasmussen, S.O., Andersen, K.K., Svensson, A.M., Steffensen, J.P., Vinther, B.M., Clausen, H.B., Siggaard-Andersen, M.L., Johnsen, S.J., Larsen, L.B., DahlJensen, D., Bigler, M., Röthlisberger, R., Fischer, H., Goto-Azuma, K. Hansson, M.E., Ruth, U., 2006. A new Greenland ice core chronology for the last glacial termination. J. Geophys. Res. D Atmos. 111, 18-28.

Rasmussen, S.O., Abbott, P.M., Blunier, T., Bourne, A.J., Brook, E., Buchardt, S.L. Buizert, C., Chappellaz, J., Clausen, H.B., Cook, E., Dahl-Jensen, D., Davies, S.M., Guillevic, M., Kipfstuhl, S., Laepple, T., Seierstad, I.K., Severinghaus, J.P. Steffensen, J.P., Stowasser, C., Svensson, A., Vallelonga, P., Vinther, B.M. Wilhelms, F., Winstrup, M., 2013. A first chronology for the North Greenland Eemian Ice Drilling (NEEM) ice core. Clim. Past 9, 2713-2730.

Rasmussen, S.O., Bigler, M., Blockley, S.P.E., Blunier, T., Buchardt, S.L., Clausen, H.B. Cvijanovic, I., Dahl-Jensen, D., Johnsen, S.J., Fischer, H., Gkinis, V., Guillevic, M., Hoek, W.Z., Lowe, J.J., Pedro, J., Popp, T., Seierstad, I.K. Steffensen, J.P. Svensson, A.M., Vallelonga, P., Vinther, B.M., Walker, M.J.C., Wheatley, J.J., Winstrup, M., 2014. stratigraphic framework for robust naming and correlation of abrupt climatic changes during the last glacial period based on three synchronized Greenland ice core records. Quat. Sci. Rev. 106, 14-28.

Reimer, P.J., Bard, E., Bayliss, A., Beck, J.W., Blackwell, P.G., Bronk Ramsey, C., Grootes, P.M., Guilderson, T.P., Haflidason, H., Hajdas, I., Hatte, C., Heaton, T.J., Homann, D.L., Hogg, A.G., Hughen, K.A., Kaiser, K.F., Kromer, B., Manning, S.W., Niu, M., Reimer, R.W., Richards, D.A., Scott, E.M., Southon, J.R., Staff, R.A. Turney, C.S.M., van der Plicht, J., 2013. IntCal13 and Marine13 radiocarbon age Calibration Curves 0-50,000 Years cal BP. Radiocarbon 55, 1869-1887.

Rosi, M., Sbrana, A. (Eds.), 1987. Phlegrean Fields. CNR Quaderni Ricerca Scientifica, vol. 114, p. 175.

Rotolo, S.G., Scaillet, S., La Felice, S., Vita-Scaillet, G., 2013. A revision of the structure and stratigraphy of pre-Green Tuff ignimbrites at Pantelleria (Strait of Sicily). J. Volcanol. Geotherm. Res. 250, 61-74.

Sarikaya, M.A., Zreda, M., Desilets, D., Ciner, A., Sen, E., 2006. Correcting for nucleogenic $36 \mathrm{Cl}$ in cosmogenic $36 \mathrm{Cl}$ dating of volcanic rocks from Erciyes volcano, Central Turkey. In: American Geophysical Union Conference, San Francisco, USA 11-15 December 2006. V21A-0553.

Scaillet, S., Vita-Scaillet, G., Rotolo, S.G., 2013. Millennial-scale phase relationships between ice-core and Mediterranean marine records: insights from highprecision ${ }^{40} \mathrm{Ar} /{ }^{39} \mathrm{Ar}$ dating of the Green Tuff of Pantelleria, Sicily Strait. Quat. Sci. Rev. 78, 141-154.

Schmitt, A., Danisik, M., Evans, N., Siebel, W., Kiemele, E., Aydin, F., Harvey, J., 2011. Acigol rhyolite field, Central Anatolia (part 1): high-resolution dating of eruption episodes and zircon growth rates. Contrib. Mineral. Petrol. 162, 1215-1231.

Seierstad, I.K., Abbott, P.M., Bigler, M., Blunier, T., Bourne, A.J., Brook, E., Buchardt, S.L., Buizert, C., Clausen, H.B., Cook, E., Dahl-Jensen, D., Davies, S.M. Guillevic, M., Johnsen, S.J., Pedersen, D.S., Popp, T., Rasmussen, S.O., Severinghaus, J., Svensson, A., Vinther, B.M., 2014. Consistently dated records from the Greenland GRIP, GISP2 and NGRIP ice cores for the past 104 ka reveal regional millennial-scale isotope gradients with possible Heinrich Event imprint. Quat. Sci. Rev. 106, 29-46.

Siani, G., Paterne, M., Michel, E., Sulpizio, R., Sbrana, A., Arnold, M., Haddad, G., 2001. Mediterranean Sea Surface radiocarbon reservoir age changes since the lastglacial maximum. Science 294, 1917-1920.

Siani, G., Sulpizio, R., Paterne, M., Sbrana, A., 2004. Tephrostratigraphy study for the last $18,000{ }^{14} \mathrm{C}$ years in a deep-sea sediment sequence for the South Adriatic. Quat. Sci. Rev. 23, 2485-2500.

Smith, V.C., Isaia, R., Pearce, N.J.G., 2011. Tephrostratigraphy and glass compositions of post-15 kyr Campi Flegrei eruptions: implications for eruption history and chronostratigraphic markers. Quat. Sci. Rev. 30, 3638-3660.

Sprovieri, M., Di Stefano, E., Incarbona, A., Salvagio, Manta, D., Pelosi, N., Ribera, d'Alcala, M., Sprovieri, R., 2013. Centennial-to millenial-scale climate oscillations in the Central-Eastern Mediterranean Sea between 20,000 and 70,000 years ago: evidence form a high-resolution geochemical and micropaleontological record. Quat. Sci. Rev. 46, 126-135.

Steffensen, J.P., Andersen, K.K., Bigler, M., Clausen, H.B., Dahl-Jensen, D., Fischer, H., Goto-Azuma, K., Hansson, M., Johnsen, S.J., Jouzel, J., Masson-Delmotte, V., Popp, T., Rasmussen, S.O., Röthlisberger, R., Ruth, U., Stauffer, B., SiggaardAndersen, M., Sveinbjörnsdóttir, Á.E., Svensson, A., White, J.W.C., 2008. Highresolution Greenland ice core data show abrupt climate change happens in few years. Science 321, 680-684.

Sulpizio, R., van Welden, A., Caron, B., Zanchetta, G., 2010. The Holocene tephrostratigraphic record of Lake Shkodra (Albania and Montenegro). J. Quat. Sci. 25, 633-650.

Svensson, A., Andersen, K.K., Bigler, M., Clausen, H.B., Dahl-Jensen, D., Davies, S.M., Johnsen, S.J., Muscheler, R., Rasmussen, S.O., Röthlisberger, R., Steffensen, J.P., Vinther, B.M., 2006. The Greenland Ice Core Chronology, 2005, 15-42 ka. Part 2: comparison to other records. Quat. Sci. Rev. 25, 3258-3267.

Svensson, A., Andersen, K.K., Bigler, M., Clausen, H.B., Dahl-Jensen, D., Davies, S.M., Johnsen, S.J., Muscheler, R., Parrenin, F., Rasmussen, S.O., Röthlisberger, R., Seierstad, I.K., Steffensen, J.P., Vinther, B.M., 2008. A 60000 year Greenland stratigraphic ice core chronology. Clim. Past 4, 47-57.

Tomlinson, E.L., Thordarson, T., Mueller, W., Thirlwall, M., Menzies, M.A., 2010. Microanalysis of tephra by LA-ICP-MS - strategies advantages and limitations assessed using the Thorsmörk ignimbrite (Southern Iceland). Chem. Geol. 279, 73-89.

Tomlinson, E.L., Arienzo, I., Wulf, S., Smith, V.C., Carandente, A., Civetta, L., Hardiman, M., Lane, C.S., Orsi, G., Rosi, M., Thirlwall, M., Muller, W. Menzies, M.A., 2012. Geochemistry of the Plegraean Fields (Italy) proximal Campi Flegrei sources for major Mediterranean tephras (C-1, C-2, Y-3 \& Y-5). Geochim. Cosmochim. Acta 93, 102-128.

Turney, C.S.M., Harkness, D.D., Lowe, J.J., 1997. The use of microtephra horizons to correlate Late-glacial lake sediment successions in Scotland. J. Quat. Sci. 12, 525-531.

Turney, C.S.M., Lowe, J.J., Davies, S.M., Hall, V., Lowe, D.J., Wastegård, S., Hoek, W.Z., Alloway, B., 2004. Tephrochronology of Last Termination Sequences in Europe: a protocol for improved analytical precision and robust correlation procedures (a joint SCOTAV-INTIMATE proposal). J. Quat. Sci. 19, 111-120.

Turney, C.S.M., van den Burg, K., Wastegård, S., Davies, S.M., Whitehouse, N.J., Pilcher, J.R., Callaghan, C., 2006. North European last Glacial-interglacial transition (LGIT; 15-10 ka) tephrochronology: extended limits and new events. J. Quat. Sci. 21, 335-345.

van den Bogaard, P., Hall, C.M., Schmincke, H.U., York, D., 1989. Precise single grain ${ }^{40} \mathrm{Ar} /{ }^{39} \mathrm{Ar}$ dating of a cold to warm climate transition in Central Europe. Nature $342,523-525$ 
Veres, D., Davies, S.M., Wohlfarth, B., Preusser, F., Wastegård, S., Ampel, L., Hormes, A., Possnert, G., Raynal, J.-P., Vernet, G., 2008. Age, origin and significance of a new middle MIS 3 tephra horizon identified within a long-core sequence from Les Echets, France. Boreas 37, 434-443.

Vernet, G., Raynal, J.P., Miallier, D., Pilleyre, T., Fain, J., Sanzelle, S., Montret, M., 1990. La retombée de la Moutade, marqueur stratigraphique de l'Alleröd en limagne septentrionale (Massif Central, France), pp. 1077-1082. Comptes rendus l'Académie des Sciences, Paris série II.

Vogel, H., Zanchetta, G., Sulpizio, R., Wagner, B., Nowaczyk, N., 2010. A tephrostratigraphic record for the last glacial-interglacial cycle from Lake Ohrid, Albania and Macedonia. J. Quat. Sci. 25, 320-338.

Wagner, B., Wilke, T., Krastel, S., Zanchetta, G., Sulpizio, R., Reicherter, K., Leng, M., Grazhdani, A., Trajanovski, S., Levkov, Z., Reed, J., Wonik, T., 2014. More than one million years of history in Lake Ohrid cores. Eos, Trans. Am. Geophys. Union 95 (3), 25-26.

Walker, M.J.C., Lowe, J.J., Blockley, S.P.E., Bryant, C., Coombs, P., Davies, S., Hardiman, M., Turney, C.S., Watson, J.A., 2012. Lateglacial palaeoenvironmental record from Sluggan Bog, Northern Ireland: comparisons with the Greenland NGRIP (GICC05) event stratigraphy. Quat. Sci. Rev. INTIMATE 36, 124-138.

Wastegard, S., 2002. Early to middle Holocene silicic tephra horizons from the Katla volcanic system, Iceland: new results from the Faroe Islands. J. Quat. Sci. 17, $723-730$.

Wastegård, S., Rasmussen, T.L., 2014. Faroe Marine Ash Zone IV: a new MIS 3 ash zone on the Faroe Islands margin. In: Austin, W., Abbott, P., Davies, S., Pearce, N., Wastegard, S. (Eds.), Marine tephrochronology: an Introduction to Tracing Time in the Ocean, Special Publications Geological Society, London, Special Publications, 398. Geological Society, London, pp. 81-93.

Wastegård, S., Wohlfarth, B., Subetto, D.A., Sapelko, T.V., 2000. Extending the known distribution of the Younger Dryas Vedde Ash into northwestern Russia. J. Quat. Sci. 15, 581-586.

Wastegård, S., Björck, S., Greve, C., Rasmussen, T.L., 2005. A tephra-based correlation between the Faroe Islands and the Norwegian Sea raises questions about chronological relationships during the last interglacial. Terra Nova 17, 7-12.
Wastegård, S., Rasmussen, T.L., Kuijpers, A., Nielsen, T., van Weering, T.C.E., 2006 Composition and origin of ash zones from Marine Isotope Stages 3 and 2 in the North Atlantic. Quat. Sci. Rev. 25, 2409-2419.

Wohlfarth, B., Blaauw, M., Davies, S.M., Andersson, M., Wastegård, Hormes, A. Possnert, G., 2006. Constraining the age of Lateglacial and early Holocene pollen zones and tephra horizons in southern Sweden with Bayesian probability methods. J. Quat. Sci. 21, 321-334.

Wulf, S., Kraml, M., Kuhn, T., Schwarz, M., Inthorn, M., Keller, J., Kuscu, I., Halbach, P., 2002. Marine tephra from the Cape Riva eruption (22 ka) of Santorini in the Sea of Marmara. Mar. Geol. 183, 131-141.

Wulf, S., Kraml, M., Brauer, A., Keller, J., Negendank, J.F.W., 2004. Tephrochronology of the 100 ka lacustrine sediment record of Lago Grande di Monticchio. Quat. Int. 122, 7-30.

Wulf, S., Kraml, M., Keller, J., 2008. Towards a detailed distal tephrostratigraphy in the Central Mediterranean: the last 20,000 yrs record of Lago Grande di Monticchio. J. Volcanol. Geotherm. Res. 177, 118-132.

Wulf, S., Keller, J., Paterne, M., Mingram, J., Lauterbach, S., Opitz, S., Sottili, G. Giaccio, B., Albert, P., Satow, C., Viccaro, M., Brauer, A., 2012. The 100-133 record of Italian explosive volcanism and revised tephrochronology of Lago Grande di Monticchio. Quat. Sci. Rev. 58, 104-123.

Wulf, S., Ott, F., Slowinski, M., Noryskiewicz, A.M., Dräger, N., Martin-Puertas, C. Czymzik, M., Neugebauer, I., Dulski, P., Bourne, A.J., Błaszkiewicz, M., Brauer, A. 2013. Tracing the Laacher See Tephra in the varved sediment record of the Trzechowskie palaeolake in central Northern Poland. Quat. Sci. Rev. 76, 129-139.

Zanchetta, G., Sulpizio, R., Giaccio, B., Siani, G., Paterne, M., Wulf, S., D'Orazio, M. 2008. The Y-3 tephra: a last glacial stratigraphic marker for the central Mediterranean basin. J. Volcanol. Geotherm. Res. 177, 145-154.

Zanchetta, G., Sulpizio, R., Roberts, N., Cioni, R., Eastwood, W.J., Siani, G., Caron, B. Paterne, M., Santacroce, R., 2011. Tephrostratigraphy, chronology and climatic events of the Mediterranean basin during the Holocene: an overview. Holocene 21, 33-52.

Zolitschka, B., 1998. Paläoklimatische Bedeutung Laminierter Sedimente. Gebr. Bornträger Verlag, Berlin, Stuttgart. 